\title{
Energy saving cement production by grain size optimisation of the raw meal
}

\section{Produção de cimento com economia de energia por otimização da granulometria da matéria prima}

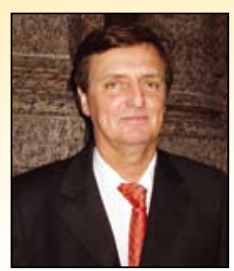

B. SIMONS a

BrunoSimons@brunosimons.de

\begin{abstract}
The production of cement clinker is an energy consuming process. At about $50 \%$ of the energy is associated with grinding and milling of the raw meal, that normally is in the range $100 \%<200 \mu \mathrm{m}$ with $90 \%<90 \mu \mathrm{m}$. Question: is it possible to use coarser components of the raw meal without reducing the clinker quality. With synthetic raw meals of various grain sizes the clinker formation was studied at static $\left(1100-1450^{\circ} \mathrm{C}\right)$ and dynamic conditions (heating microscope). A routine to adjust the grain size of the components for industrial raw meals is developed. The fine fraction $<90 \mu \mathrm{m}$ should mainly contain the siliceous and argileous components, whereas the calcitic component can be milled separately to a grain size between 200-500 $\mu \mathrm{m}$, resulting in lower energy consumption for milling. Considering the technical and economical realizability the relation fine/coarse should be roughly $1: 1$. The energy for milling can be reduced significantly, that in addition leads to the preservation of natural energy resources.
\end{abstract}

Keywords: Cement production, energy saving, electron microprobe, heating microscopy

\section{Resumo}

A produção de clínquer é um processo que envolve alto consumo de energia. Cerca de $50 \%$ da energia é associada com trituração e moagem da matéria prima, que normalmente está no intervalo $100 \%<200 \mu \mathrm{m}$ com $90 \%<90 \mu \mathrm{m}$. Pergunta: é possível usar componentes maiores da matéria prima sem reduzir a qualidade do clínquer? Com matérias primas sintéticas de granulometria variada a formação do clínquer foi estudada em condições estática $\left(1100-1450^{\circ} \mathrm{C}\right)$ e dinâmica (microscópio de aquecimento). Uma rotina para ajustar a granulometria dos componentes para materias primas industriais foi desenvolvida. A fração fina < $90 \mu \mathrm{m}$ deve conter principalmente componentes silicáceos e argilosos, enquanto o componente calcítico pode ser moído separadamente para uma granulometria entre 200-500 $\mu \mathrm{m}$, resultando um menor consumo de energia para a moagem. Considerando a viabilidade técnica e econômica a relação finos/ graúdos deve ser aproximadamente 1:1. A energia para moagem pode ser reduzida significativamente, o que adicionalmente conduz à preservação de recursos energéticos naturais.

Palavras-chave: Produção de cimento, economia de energia, microssonda eletrônica, microscopia de aquecimento.

\footnotetext{
Institut für Geologie und Mineralogie, Abteilung für Angewandte Mineralogie, Universität zu Köln, BrunoSimons@brunosimons.de, Zülpicher Strasse 49b, 50674 Köln, Deutschland
} 


\section{Introduction}

Compared to other industries cement production is an energy intensive process. Besides big energy reductions in the last years due to improvements in the preparation of raw materials, kiln development and heat recovery, a further reduction of energy by an extreme coarsening of the raw meal (up to $2000 \mu \mathrm{m}$ grain size) is discussed. In the proposed process the energy consumption and operational costs shall be reduced by lowering the energy for milling, prolongation of the life time for the mills, lowering the sintering temperatures and shortening the reaction times in the rotary kiln, resulting in at least $30 \%$ energy reductions. It was supposed in a patent (Lörke, 2001 [1]), that the raw meal should be milled separated in a fine fraction of grain size $<80 \mu \mathrm{m}\left(\mathrm{SiO}_{2}, \mathrm{Al}_{2} \mathrm{O}_{3}\right.$ rich $)$ and a coarse fraction up to $2 \mathrm{~mm}$ ( $\mathrm{CaO}$ rich) in a relation $1,5: 1$ up to 1 $: 9$. Thus at the sintering process the composition of the fine fraction is only sufficient to form $C S$ and/or $C_{3} S_{2}$ as well as $C_{2} A S, C_{3} A$, $\mathrm{C}_{12} \mathrm{~A}_{7}$ and $\mathrm{C}_{4} \mathrm{FA}$.

With respect to the system $\mathrm{CaO}-\mathrm{Al}_{2} \mathrm{O}_{3}-\mathrm{SiO}_{2}$ (CAS) (figure. 1) a first eutectic with CS (Wollastonite), $\mathrm{C}_{3} \mathrm{~S}_{2}$ (Rankinite) and $\mathrm{C}_{2} \mathrm{AS}$ (Gehlenite) at $1265^{\circ} \mathrm{C}$ will be established. A further eutectic would be $C_{2} A S$ (Gehlenite), $C_{3} A$ and $C_{12} A_{7}$. However, the later one is stably

\section{Figure 1 - The system $\mathrm{CaO}-\mathrm{Al}_{2} \mathrm{O}_{3}-\mathrm{SiO}_{2}$, (modified after Rankin and Wright, 1915 (2)) in weight percent. Alkemadelines, red, connecting the subsolidus phases, and the resulting Alkemade triangles point to the according eutectics resp. peritectics listed above.}

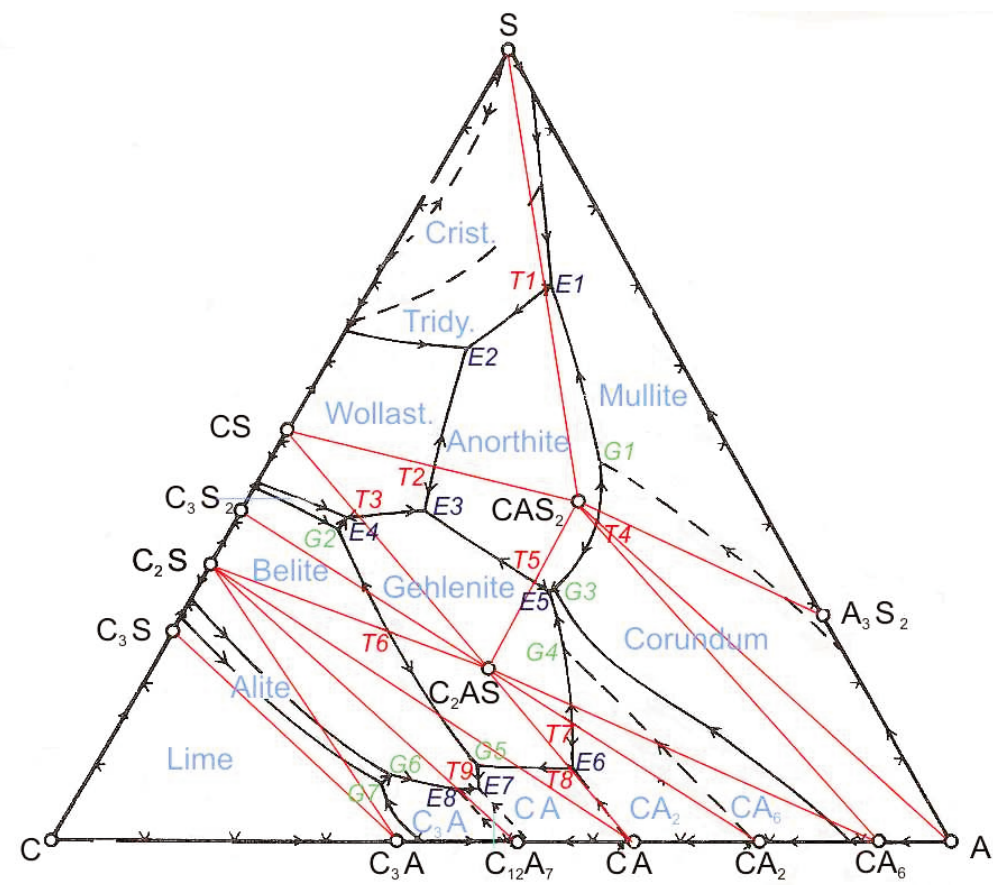

\section{Thermal divide}

\begin{tabular}{|c|c|}
\hline 1: Tri/Ano & $1368^{\circ} \mathrm{C}$ \\
\hline T2: Wol/Ano & 13 \\
\hline T3: Wol/Geh & \\
\hline T4: Ano/Cor & \\
\hline T5: Ano/Geh & \\
\hline Geh/C $\mathrm{C}_{2} \mathrm{~S}$ & \\
\hline Seh/CA2 & \\
\hline $\mathrm{S} / \mathrm{C}_{10} \mathrm{~A}_{7}$ & \\
\hline
\end{tabular}

Distributary point

G1: Cor/Mul/Ano

G2: Ran/Geh/C2S

G3: Ano/Cor/CA。

G4: Geh/CA $/ \mathrm{A}_{2} / \mathrm{A}_{6}$

G5: $\mathrm{C}_{2} \mathrm{~S} / \mathrm{Geh} / \mathrm{CA}$

G6: $\mathrm{C}_{3} \mathrm{~S} / \mathrm{C}_{2} \mathrm{~S} / \mathrm{C}_{3} \mathrm{~A}$

G7: $\mathrm{CaO} / \mathrm{C}_{3} \mathrm{~S}_{3} \mathrm{C}_{3} \mathrm{~A}$

$1512^{\circ} \mathrm{C}$
$1315^{\circ} \mathrm{C}$
$1405^{\circ} \mathrm{C}$
$1475^{\circ} \mathrm{C}$
$1380^{\circ} \mathrm{C}$
$1455^{\circ} \mathrm{C}$
$1470^{\circ} \mathrm{C}$

$1512^{\circ} \mathrm{C}$

$315^{\circ} \mathrm{C}$

$380^{\circ} \mathrm{C}$

$470^{\circ} \mathrm{C}$
Eutectic

E1: Tri/Ano/Mul

$1345^{\circ} \mathrm{C}$

E2: Tri/Ano/Wol

$1170^{\circ} \mathrm{C}$

E3: Geh/Ano/Wol

$1265^{\circ} \mathrm{C}$

E4: Wol/Ran/Geh

$1310^{\circ} \mathrm{C}$

E5: Ano/Geh/CA6 $1380^{\circ} \mathrm{C}$

E6: Geh/CA/CA2 $\quad 1500^{\circ} \mathrm{C}$

E7: $\mathrm{C}_{2} \mathrm{~S} / \mathrm{C}_{1} \mathrm{~A}_{7} / \mathrm{CA} \quad 1335^{\circ} \mathrm{C}$

E8: $\mathrm{C}_{12} \mathrm{~A}_{7} / \mathrm{C}_{3} \mathrm{~A} / \mathrm{C}_{2} \mathrm{~S} \quad 1335^{\circ} \mathrm{C}$

Abbreviations: Crist. $=$ Cristobalite; Tridy. $=$ Tridymite; Wollast. $=$ Wollastonite; $\mathrm{C}_{3} \mathrm{~S}_{2}=$ Rankinite 


\section{Table 1 - Composition and fine/coarse ratio}

\begin{tabular}{|c|c|c|c|}
\hline \multicolumn{4}{|c|}{ Synthetic mixłure with CAS 65/10/25 } \\
\hline Component & Source & Weight \% & $\mu \mathrm{m}$ \\
\hline $\mathrm{CaO}$ & $\begin{array}{c}\text { Calcite (Merck, 102066) } \\
\text { Warsteiner Kalk }\end{array}$ & 74,58 & $\begin{array}{c}<14 \\
200-500\end{array}$ \\
\hline $\mathrm{Al}_{2} \mathrm{O}_{3}$ & $\begin{array}{c}\text { Kaolinite } \\
\text { (Amberger Kaolinwerke, TEC FF840 }\end{array}$ & 18,37 & $<0,9$ \\
\hline $\mathrm{SiO}_{2}$ & $\begin{array}{l}\text { Quartzpowder } \\
\text { (Quarzwerke Frechen, Sikron SF600 }\end{array}$ & 7,02 & $<3$ \\
\hline Sample & ratio fine/coarse & & \\
\hline $\begin{array}{c}\text { fine } \\
\text { coarse } \\
\text { "super coarse" }\end{array}$ & $\begin{array}{c}1: 0 \\
1: 1 \\
1: 2,94\end{array}$ & $\begin{array}{r}\text { Calcite + Wa } \\
\text { only Warstei } \\
\text { CaO cor }\end{array}$ & $\begin{array}{l}\text { steiner Kalk } \\
\text { er Kalk as } \\
\text { iponent }\end{array}$ \\
\hline
\end{tabular}

non existent, since the kinetic favoured formation of $\mathrm{C}_{2} \mathrm{~S}$ (Belite) establishes the peritectics $\mathrm{C}_{3} \mathrm{~S}_{2} / \mathrm{C}_{2} \mathrm{AS} / \mathrm{C}_{2} \mathrm{~S}\left(1315^{\circ} \mathrm{C}\right)$ and $\mathrm{C}_{2} \mathrm{~S} / \mathrm{C}_{2} \mathrm{AS} /$ $\mathrm{CA}\left(1380^{\circ} \mathrm{C}\right)$, as well as the eutectics $\mathrm{C}_{2} \mathrm{~S} / \mathrm{C}_{12} \mathrm{~A}_{7} / \mathrm{CA}\left(1335^{\circ} \mathrm{C}\right)$ and $\mathrm{C}_{2} \mathrm{~S} / \mathrm{C}_{12} \mathrm{~A}_{7} / \mathrm{C}_{3} \mathrm{~A}\left(1335^{\circ} \mathrm{C}\right)$.

Right here it should be emphasised, that in a conventional rotary kiln process the first melt formation at about $1280^{\circ} \mathrm{C}$ (Taylor: „Cement Chemistry“, 1997 [3]) occurs, thus in the range of the eutectic $\mathrm{CS} / \mathrm{C}_{3} \mathrm{~S}_{2} / \mathrm{C}_{2} \mathrm{AS}$.

This paper describes experimental results on synthetic and industrial raw meals, where the attempt was made to coarsen one or more components of the raw meal and achieve a lower eutectic. The basics of the experimental results and the thermodynamically background of the observed equilibria and the technical realization is described.

\section{Materials and experimental program}

The respective portions were weight for a total of $100 \mathrm{~g}$ and the samples were then homogenized for 2 hours. Aliquots of $5 \mathrm{~g}$ were then pressed to tablets $2 \mathrm{~cm}$ in diameter. Two of each mixture were heated up in a high temperature furnace with a rate of $15^{\circ} \mathrm{C} / \mathrm{min}$ and held for 30 minutes at $1150,1250,1300,1350$ and $1450^{\circ} \mathrm{C}$. The samples were quenched in a stream of compressed air. Sample preparation and experimental procedure for the Heating microscope is described in section 4.

\subsection{Sample analysis}

The samples were microscopically inspected in reflected light (etched samples), by x-ray diffraction (XRD) and by electron probe micro analysis (EPMA). Free lime was analysed wet-chemically.

\section{Results}

\subsection{Calculation of Phase content from free lime content}

From the analysed free lime content and the initial composition of the sample the composition of the "remaining sample" can be calculated and the resulting Alkemade-triangle determined, thus the eutectic/peritectic at a sufficient temperature can be precast (figure 2).

\subsection{Reaction paths of the analysed samples}

\subsubsection{Sample "fine"}

The sample "fine" develops in the temperature range $1150-1450^{\circ} \mathrm{C}$ in accordance to the phase relations in the CAS system. The freelime calculation as shown in figure 2 leads at $1150^{\circ} \mathrm{C}$ to a composition CAS 58,09/11,97/29,94 and thus in the Alkemade-triangle Belite - CA - Gehlenite. With increasing temperature and consumption of $\mathrm{CaO}$ the Alkemade-triangles Belite $-\mathrm{C}_{12} \mathrm{~A}_{7}-\mathrm{CA}$; Belite $-\mathrm{C}_{3} \mathrm{~A}$ $-C_{12} A_{7}$ are passed and finally the clinker-assemblage Alite - Belite $-\mathrm{C}_{3} \mathrm{~A}$ is established resulting in a homogeneous clinker.

\subsubsection{Sample "coarse"}

The sample "coarse" composition at $1150^{\circ} \mathrm{C}$ is CAS $50,7 / 14,08 / 35,21$ (after free-lime reduction) and thus in the triangle Rankinite - Gehlenite - Wollastonite. However, at $1150^{\circ} \mathrm{C}$ beside Gehlenite Belite is observed by XRD as a result due to its kinetically favoured formation at low temperatures (Lindner, 1955 [4]). At $1250^{\circ} \mathrm{C}$ Rankinite and Wollastonite in addition are observed, in especial by EPMA.

Finally at $1300^{\circ} \mathrm{C}$ a CAS $54,09 / 13,12 / 32,80$ is calculated and due to it's phase relation Belite - Gehlenite - Rankinite a melt is observed (nominally at $1310^{\circ} \mathrm{C}$ in the eutectic E4, see figure 1). With increasing temperature the melt composition develops to the tributary point $\mathrm{G} 2\left(1315^{\circ} \mathrm{C}\right)$, then follows the cotectical line Belite - Rankinite and then passes the liquidus of Belite to the cotectical line Belite - Gehlenite. The thermal divide T6 $\left(1545^{\circ} \mathrm{C}\right)$ must be "tunnelled" by partial recrystallisation of the melt before it reaches the cotectical line Belite - Gehlenite again, passing the Belite liquidus at the $1450^{\circ} \mathrm{C}$ to the cotectical line Belite $-C_{3} A$. Further incorporation of $\mathrm{CaO}$ finally leads to the formation of Alite. 
Figure 2 - CAS-Free-lime relation, modified system CAS. After subtraction of the analysed free-lime content from the initial composition (lower red dot) the remaining $\mathrm{CaO}$ reduced composition (upper red dot) results.

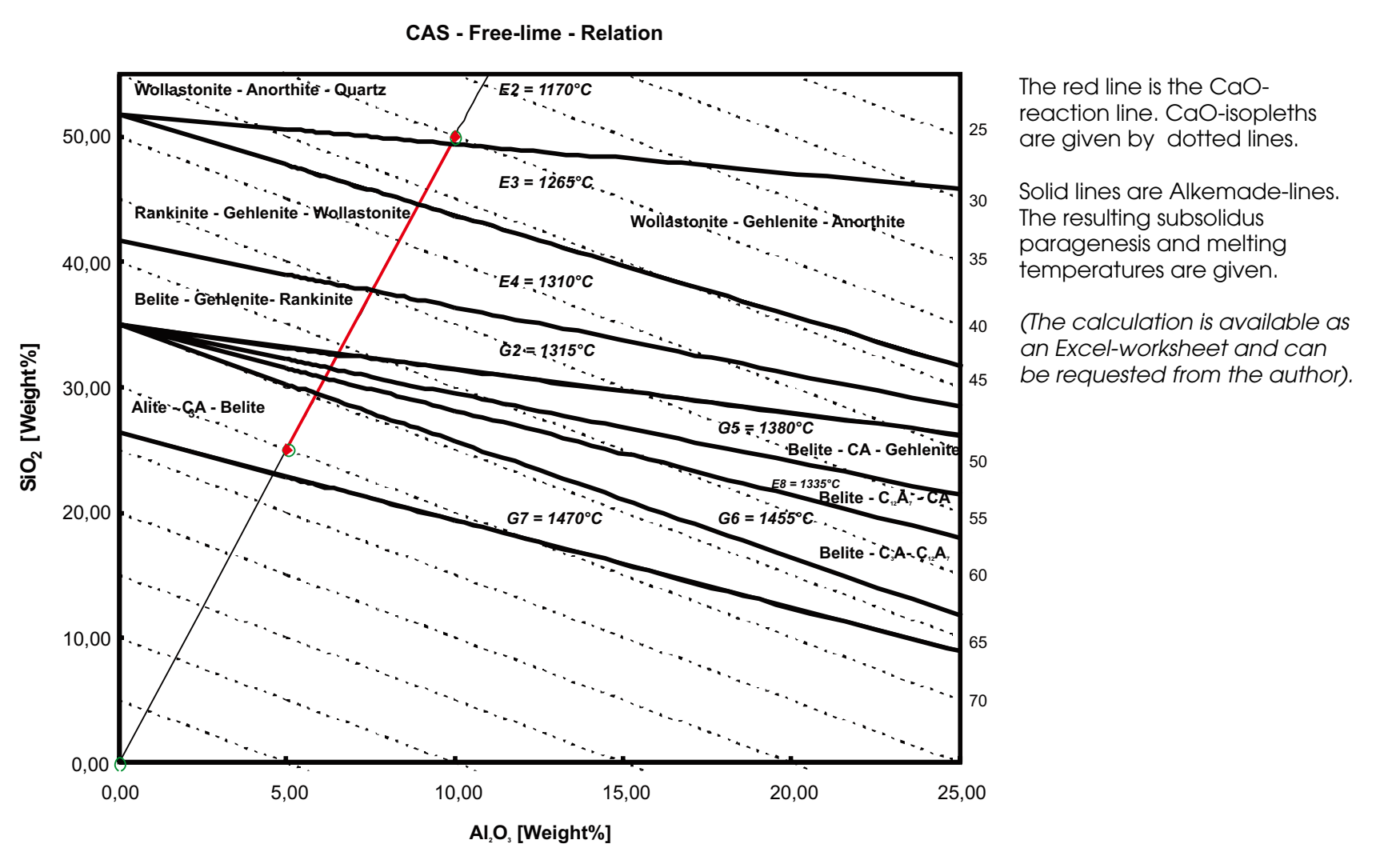

Figure 3 - Sample "coarse" $1300^{\circ} \mathrm{C}$. Semi quantitative EPMA. Note the strong maxima for Belite and melt. Gehlenite is weakly developed. At the $\mathrm{CaO}$ apex is free lime. Also note the trends following the Alkemade lines to $C_{3} A$ and $C_{12} A_{7}$

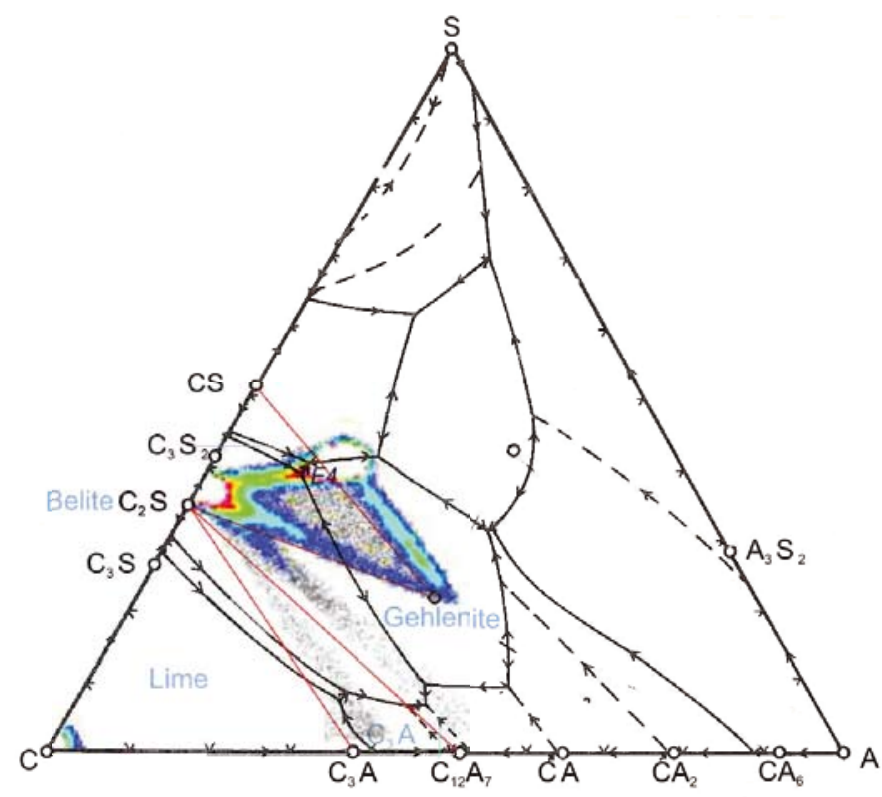




\section{Figure 4 - a), b) (below) | Sample "coarse" $1300^{\circ} \mathrm{C}$}

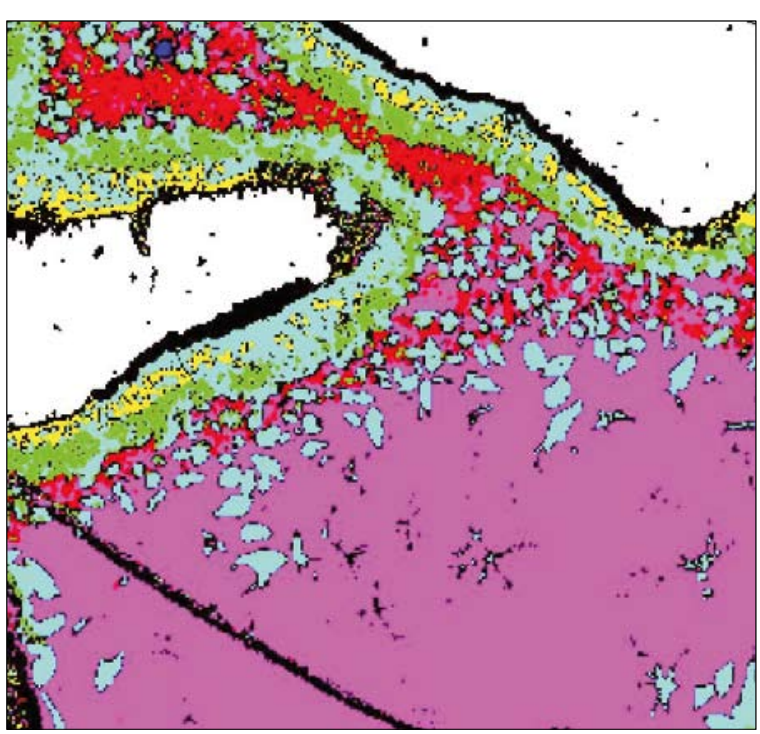

a) Elementmapping: White: free lime; Magenta: melt light blue: Belite; red: Gehlenite; yellow and green: nonstochiometric Belites.

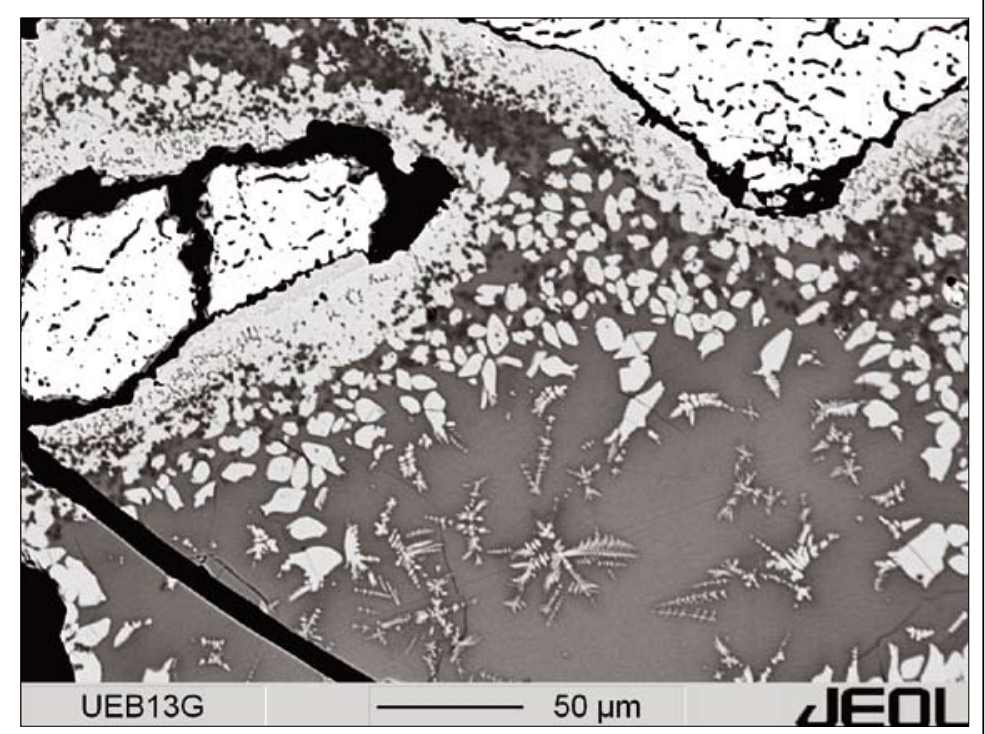

b) Backscattering image: note the typical Belite exsolutions (quench crystals) in the melt.

\subsubsection{Sample "super coarse"}

The sample "super coarse" composition at $1150^{\circ} \mathrm{C}$ is with CAS $17,86 / 23,47 / 58,67$ in the triangle Wollastonite-Anorthite - $\mathrm{SiO}_{2}$. By EPMA only a limited reaction of the sample and no partial melting is observed.
At $1250^{\circ} \mathrm{C}$ by EPMA beside Wollastonite and Gehlenite a melt is detected. The composition of the melt is within the thermal divide T3. In addition Belite is observed, which by reaction of free $\mathrm{CaO}$ with Wollastonite due to kinetic reason develops. Due to this kinetically favourable reaction to Belite, Rankinite is not

Figure 5 - sample "super coarse" - $1250^{\circ} \mathrm{C}$. Ternary plot of semi quantitative EPMA super-positioned on the CAS system. Note the maxima for Belite, Gehlenite and Wollastonite. On the thermal divide T3 the maximum for the melt composition is shown. The maximum in the CaO apex is free lime.

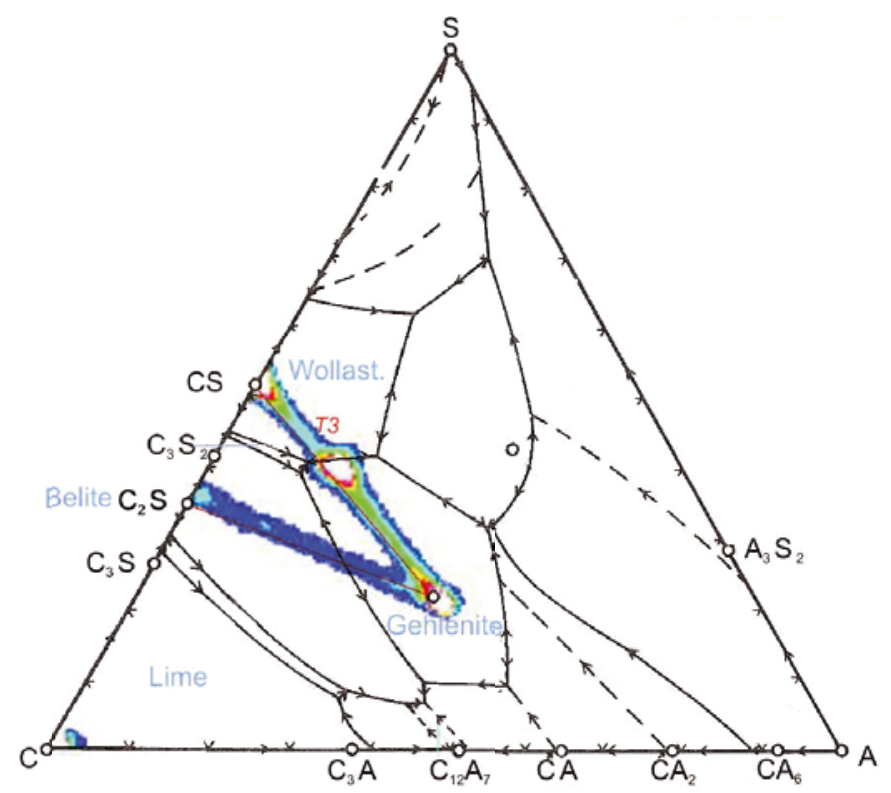


Figure 6 - sample "super coarse" - $1250^{\circ} \mathrm{C}$. Elementmapping: light-blue: Belite; yellow: Wollastonite; magenta: Gehlenite; green: trend to Aluminate; pink: free lime; red: melt.

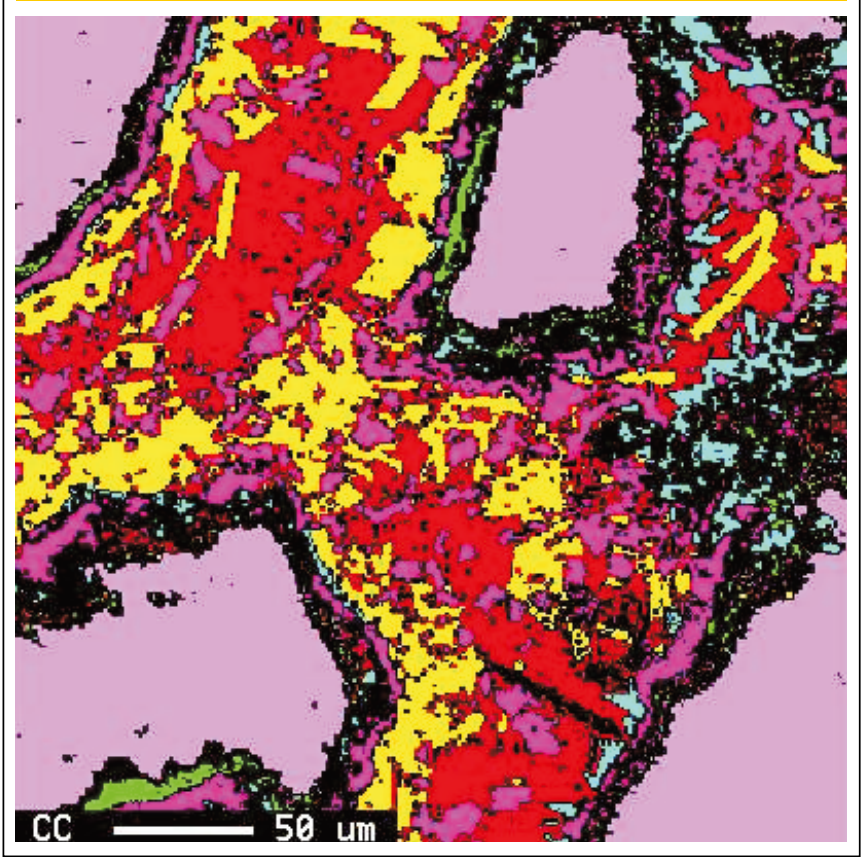

Figure 7 - sample "fine" - $1250^{\circ} \mathrm{C}$, EPMA Backscattering image. In a decarbonised Calcite a Quartz-crystal with well developed pyramidal ends is embedded. The reaction-rim (about 1,5-2 $\mu \mathrm{m}$ ) is analysed to be Belite.

In addition Gehlenite, Wollastonite and Rankinite is observed.

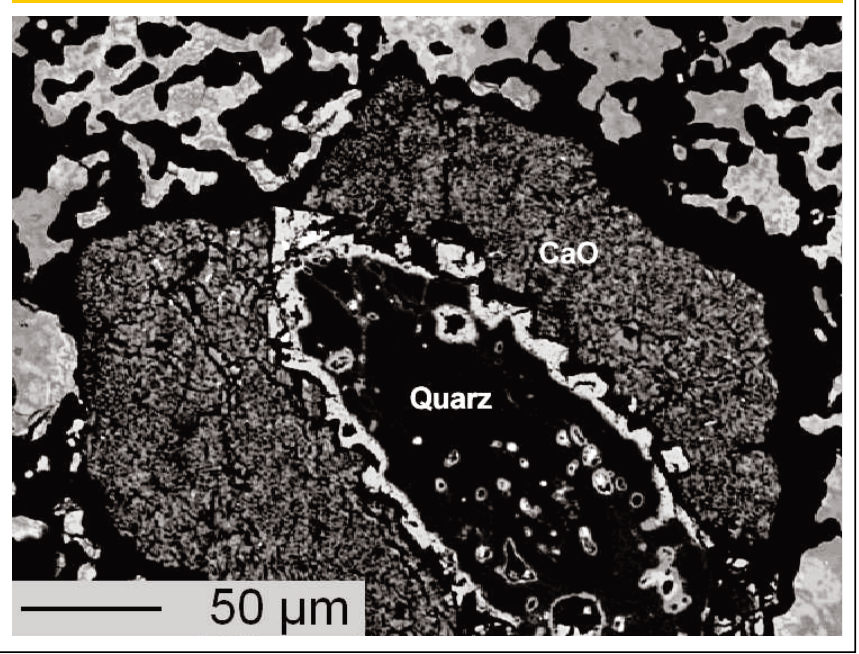

Figure 8 - Sample "fine" - $1150^{\circ} \mathrm{C}$, EPMA Elementmapping. A coarse Metakaolinite (green) is surrounded by a rim of Anorthite (yellow).

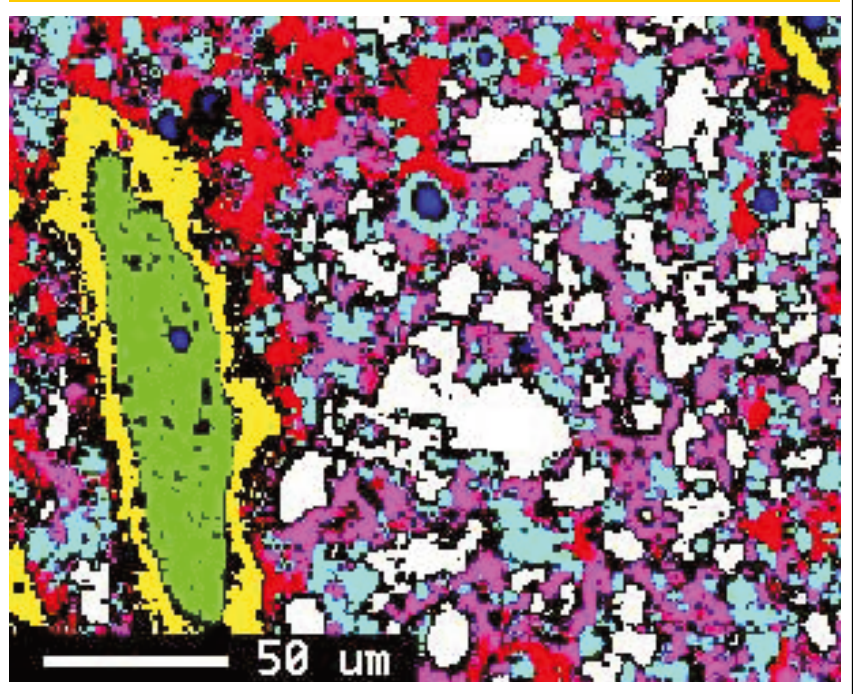

Figure 9 - Sample "fine" - $1250^{\circ} \mathrm{C}$. Now a metakaolinite (green) is surrounded by Gehlenite (red).

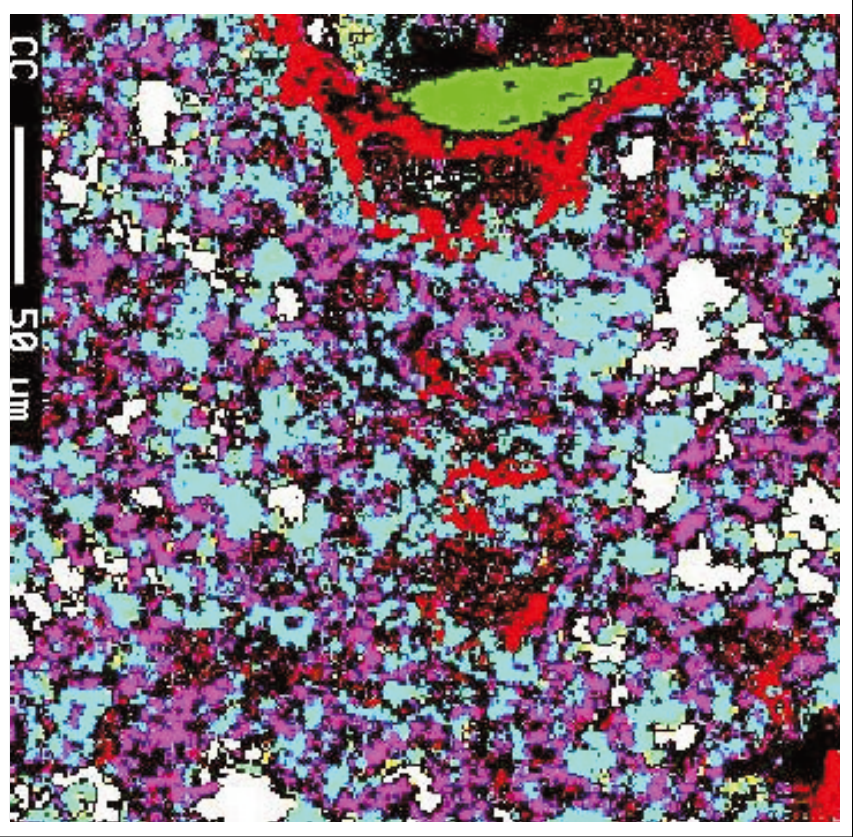

observed. The composition of the melt seems to remain at the thermal divide.

Theoretically the melt should consume $\mathrm{CaO}$ with increasing temperature and develop to the eutectic $\mathrm{E} 4$ at $1310^{\circ} \mathrm{C}$. In fact, at $1300^{\circ} \mathrm{C}$ a CAS $53,80 / 13,20 / 33,00$ indicates the distribution point 
Figure 10 - Reaction path in the CAS system (mole \%). Solid lines are Alkemade-lines. Black wide dotted lines as indicated. The narrow dotted blue line indicates the reaction of $\mathrm{SiO}_{2}$ with $\mathrm{CaO}$; the red dotted line indicates the reaction of Metakaolinite with $\mathrm{CaO}$.

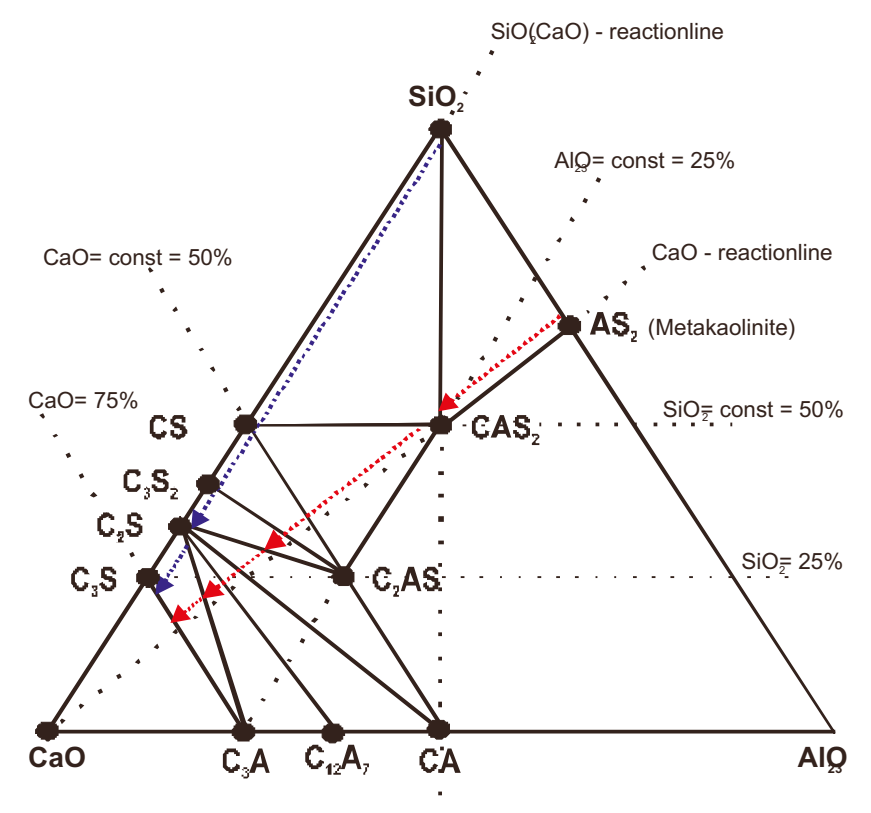

G2 with coexisting Belite - Gehlenite - Rankinite. Further increase in temperature up to $1450^{\circ} \mathrm{C}$, consumption of free $\mathrm{CaO}$, leads to the cotectic line Belite - Gehlenite and develops as described above for the sample "coarse".

At $1450^{\circ} \mathrm{C}$ the Clinker-assemblage is observed.

By reflected light microscopy as by EPMA as well typically rounded Belites in the range of $20-50 \mu \mathrm{m}$ and prismatic Alites up to 60 $\mu \mathrm{m}$ are observed. The axial ratio is $2: 1$ for the Alites. A free lime content of 1,45 is within an acceptable range for industrial clinkers. The texture is homogenous with low porosity.

It thus seems possible with the above experimental approach to achieve a "lower melting" eutectic $\left(E 3: 1265^{\circ} \mathrm{C}\right)$ despite intense coarsening of the calcitic component of the raw meal; however, resulting in a technical acceptable clinker.

But it has to be mentioned, that the fine fraction of the above raw meals was $<10 \mu \mathrm{m}$ in the average, thus by one decade lower as for industrial raw meals.

\subsection{Reaction paths in the System $\mathrm{CaO}-\mathrm{Al}_{2} \mathrm{O}_{3}-\mathrm{SiO}_{2}$}

The analysed synthetic samples, especially those in the subsolidus region demonstrate that two different primary reactions occur. At one hand the reaction of Quartz with $\mathrm{CaO}$ (figure 7), which leads to the kinetically favoured formation of Belite (see 3.4); at the other hand the reaction of Metakaolinite with $\mathrm{CaO}$ (figure 8 and 9), leading over the formation of an anorthitic component to the Alkemade relations shown in figure 10 .

Assuming a heterogeneous sample, where after decarbonatisation of the calcitic component and dehydration resp. dehydrolisation of the argileous components to in exemplo Metakaolinite, the free $\mathrm{SiO}_{2}$ reacts with $\mathrm{CaO}$ to Belite (kinetically favoured) and Metakaolinite reacts with $\mathrm{CaO}$ to an anorthitic phase and consequently to Gehlenite and Belite, a first melt will establish in one of the Alkemade-triangles Belite - Gehlenite - (Wollastonite/Rankinite). A paragenesis Wollastonite - Anorthite $\mathrm{SiO}_{2}$ at nominally $\mathrm{E} 2=1170^{\circ} \mathrm{C}$ will never be achieved. However, when reactions of $\mathrm{SiO}_{2}$ with $\mathrm{CaO}$ at higher temperatures lead to the formation of Wollastonite and/or Rankinite occur, local heterogeneities may led to a partial melting with the anorthitic component to E3.

\subsection{The Belite "problem"}

At the binary join $\mathrm{CaO}-\mathrm{SiO}_{2}$ the phases Lime, $\mathrm{CaO}$; Alite, Ca${ }_{3} \mathrm{SiO}_{5 ;}$, Belite, $\mathrm{Ca}_{2} \mathrm{SiO}_{4 ;}$ Rankinite, $\mathrm{Ca}_{3} \mathrm{Si}_{2} \mathrm{O}_{7}$, Wollastonite, $\mathrm{CaSiO}_{3}$; and Quartz, $\mathrm{SiO}_{2}$ occur.

The reactions of the binary phases from the oxides are given with: Alite: $\mathrm{SiO}_{2}+3 \mathrm{CaO}>\mathrm{Ca}_{3} \mathrm{SiO}_{5}$

Belite: $\mathrm{SiO}_{2}+2 \mathrm{CaO}>\mathrm{Ca}_{2} \mathrm{SiO}_{4}$

Rankinite: $2 \mathrm{SiO}_{2}+3 \mathrm{CaO}>\mathrm{Ca}_{3} \mathrm{Si}_{2} \mathrm{O}_{7}$

Wollastonite: $\mathrm{SiO}_{2}+\mathrm{CaO}>\mathrm{CaSiO}_{3}$

Considering the available $\mathrm{Cp}$ data, the free energies of reaction demonstrate that Belite has the lowest values over the whole temperature range.

The self diffusion constants for Calcium were given by Lindner (1955 [4]):

Wollastonite: $D=7{ }^{*} 10^{4} \exp (-112.000 / R T)\left[\mathrm{cm}^{2} / \mathrm{sec}\right] \mathrm{T}: 1130-1400^{\circ} \mathrm{C}$ $\mathrm{D}=0,2 \exp (-78.000 / \mathrm{RT})\left[\mathrm{cm}^{2} / \mathrm{sec}\right] \mathrm{T}:>1400^{\circ} \mathrm{C}$

Rankinite: $\mathrm{D}=0,1 \exp (-73.000 / \mathrm{RT})\left[\mathrm{cm}^{2} / \mathrm{sec}\right] \mathrm{T}:<1260^{\circ} \mathrm{C}$

Belite: $\mathrm{D}=3,6^{*} 10^{-2} \exp (-65.000 / \mathrm{RT})\left[\mathrm{cm}^{2} / \mathrm{sec}\right] \mathrm{T}:<1370^{\circ} \mathrm{C}$

$\mathrm{D}=2,0^{*} 10^{-2} \exp (-55.000 / \mathrm{RT})\left[\mathrm{cm}^{2} / \mathrm{sec}\right] \mathrm{T}:>1400^{\circ} \mathrm{C}$

and are sketched in figure 11. 
Table 2 - Standard state values

\begin{tabular}{|c|c|c|c|c|}
\hline & & $\begin{array}{c}\mathrm{H}^{\circ} 298,1 \\
\text { (kJ/mole) }\end{array}$ & $\begin{array}{c}S^{\circ} 298,1 \\
\left(\mathrm{~J} / \mathrm{mole}^{*} \mathrm{~K}\right)\end{array}$ & reference \\
\hline Quartz & $\mathrm{SiO}_{2}$ & $-910,70$ & 41,46 & Saxena et al. (4) \\
\hline Lime & $\mathrm{CaO}$ & $-634,26$ & 38,10 & Saxena et al. (4) \\
\hline Wollastonite & $\mathrm{CaSiO}_{3}$ & $-1.632,00$ & 82,03 & Saxena et al. (4) \\
\hline Rankinite & $\mathrm{Ca}_{3} \mathrm{Si}_{2} \mathrm{O}_{7}$ & $-3.842,60$ & 210,90 & Kubachewski et al (5) \\
\hline Belite & $\mathrm{Ca}_{2} \mathrm{SiO}_{4}$ & $-2.305,98$ & 127,61 & Robie et al (6) \\
\hline Alite & $\mathrm{Ca}_{3} \mathrm{SiO}_{7}$ & $-2.928,80$ & 168,60 & Kubachewski et al (5) \\
\hline
\end{tabular}

\begin{tabular}{|c|c|c|c|}
\hline \multicolumn{4}{|c|}{ Table 3 - Free Enthalpy of formation } \\
\hline & $\begin{array}{c}\Delta \mathbf{G}^{\circ}{ }_{298,1} \\
\text { (kJ/mole) }\end{array}$ & $\begin{array}{c}\Delta \boldsymbol{G}^{\circ}{ }_{1000,1} \\
(\mathrm{~kJ} / \mathrm{mole})\end{array}$ & $\begin{array}{c}\Delta \boldsymbol{G}^{\circ}{ }_{1750,1} \\
(\mathrm{~kJ} / \mathrm{mole})\end{array}$ \\
\hline Wollastonite & $-87,78$ & $-89,51$ & $-91,36$ \\
\hline Rankinite & $-122,50$ & $-132,10$ & $-142,36$ \\
\hline Belite & $-129,73$ & $-136,71$ & $-144,17$ \\
\hline Alite & $-119,15$ & $-128,16$ & $-137,79$ \\
\hline
\end{tabular}

Figure 11 - Diffusion-constants for Belite (line - dot), Rankinite (dotted line) und Wollastonite (solid line). In addition a dotted line is shown representing the eutectic temperature with $1460^{\circ} \mathrm{C}$ for Rankinite and Wollastonite.

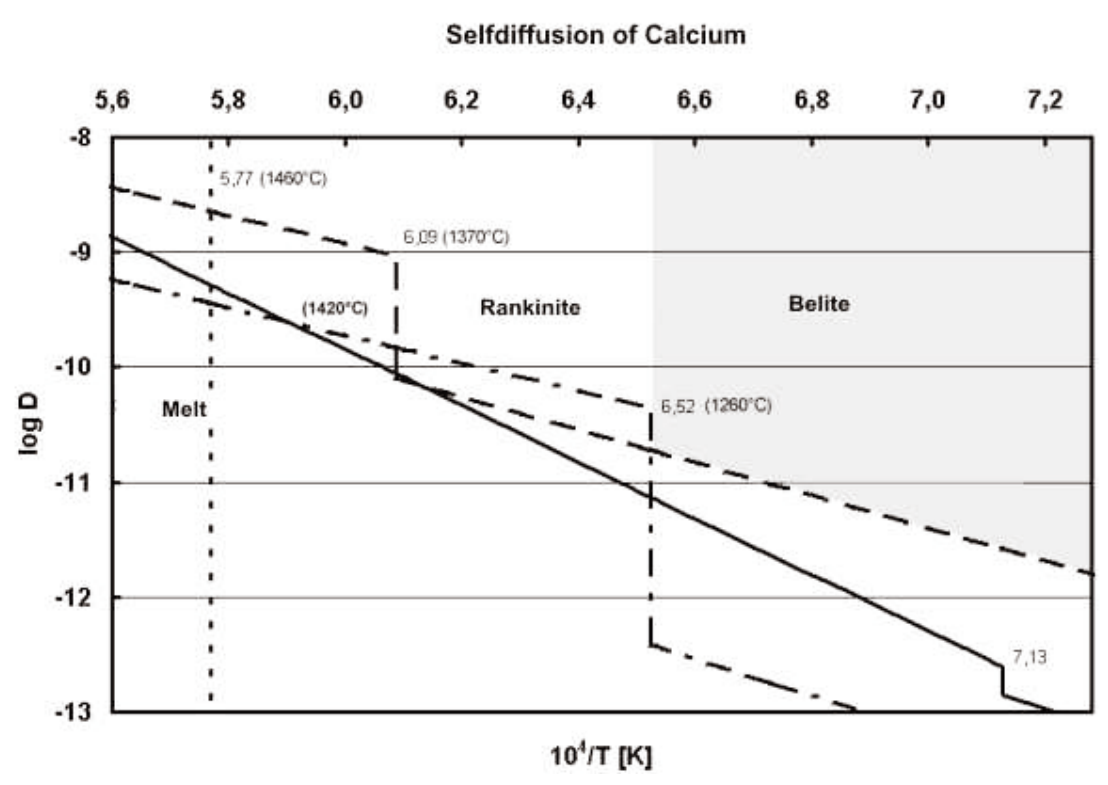




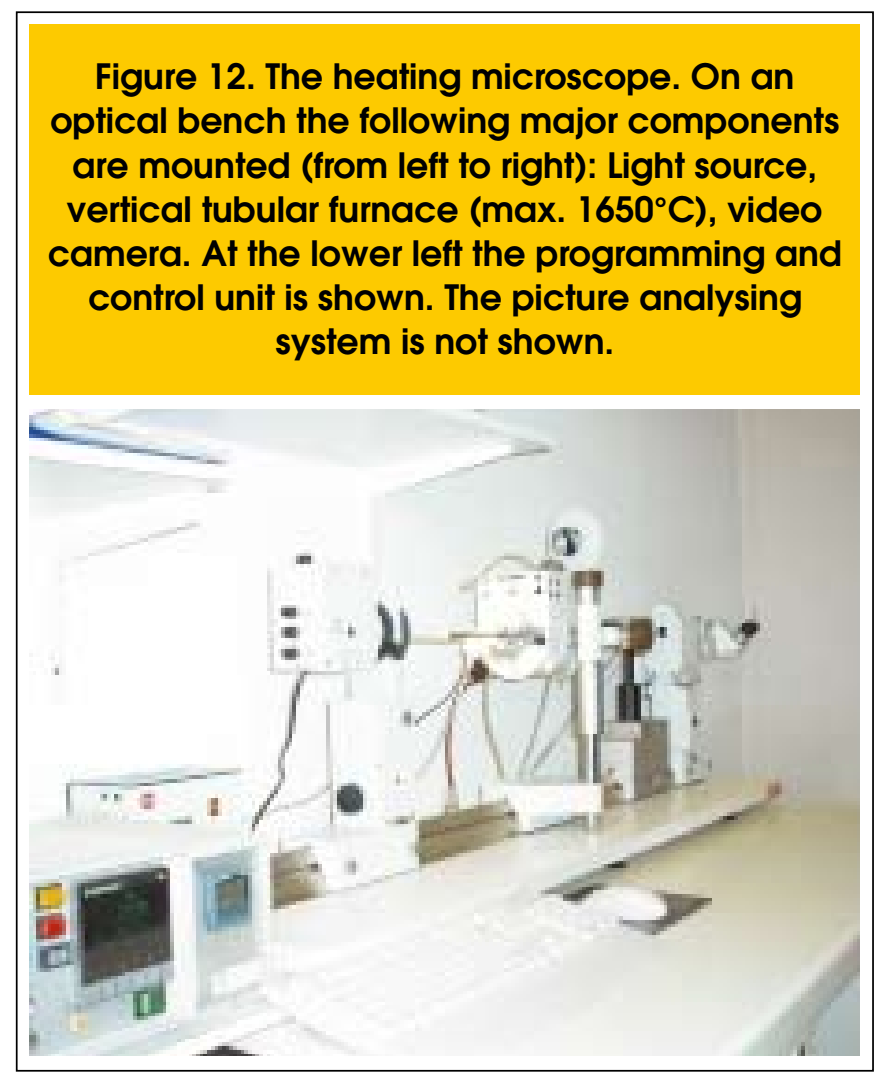

According to Lindner (1955 [4]) the early occurrence of Belite is thus explained.

In the present study a sample of fine grain size, being with its overall chemistry within the ternary Alkemade triangle Rankinite - Gehlenite - Wollastonite, at $1150^{\circ} \mathrm{C}$ only Belite and Gehlenite could be detected; at an according coarse grained sample beside Belite, Rankinite and Wollastonite were observed. In fine as well coarse samples, having the overall composition in the ternary Alkemade triangle Wollastonite - Anorthite $-\mathrm{SiO}_{2}$, the respective subsolidus phase assemblage was achieved.

It thus has to be pointed out, given a composition above the Alkemade-line Wollastonite - Anorthite $\left(\mathrm{SiO}_{2}\right.$-rich), Wollastonite is formed. Consequently at $\mathrm{CaO}$ - contents below the Alkemade-line Wollastonite-Anorthite the formation of Wollastonite follows over the primary formation of Belite and then Rankinite. This is demonstrated in figure 7 , where a $\mathrm{SiO}_{2}$ grain imbedded in the groundmass is surrounded by a Belite rim.

\section{Heating Microscope}

\subsection{Sample preparation and experimental procedure}

Synthetic samples fine and coarse as described in section 2 as well as various industrial raw meals were pressed to cubes with $3 \mathrm{~mm}$ length and placed on an $\mathrm{Al}_{2} \mathrm{O}_{3}$ sample holder. The sample holder was sled into a tubular furnace preheated to $500^{\circ} \mathrm{C}$. The temperature was registered with an EL18 thermocouple placed right under the sample. The temperature was then linearly raised with $10^{\circ} \mathrm{C} / \mathrm{min}$ up to 1450 $\sim 1500^{\circ} \mathrm{C}$. The sample was illuminated inline of an optical bench, and its shadow was registered by a video device. Thus with a picture analysing system the surface resp. volume decrease was monitored. Thermal events as sintering, softening and others can be monitored.

\subsection{Results}

Sample "fine" (1) only shows a decrease in volume at about $1200^{\circ} \mathrm{C}$ and then a drastic decrease at $1463^{\circ} \mathrm{C}$ - melting. However the coarse sample decreases in volume at about $800-900^{\circ} \mathrm{C}$ (decarbonatization, sintering), then shows a slight decrease at about $1230-1260^{\circ} \mathrm{C}$ (eutectic E3: $1265^{\circ} \mathrm{C}$ ) and a softening temperature of $1310^{\circ} \mathrm{C}$ (partial melting in the eutectic E4). This is in total agreement with the static experiments.

All industrial raw meals show similar behaviour to the synthetic sample "coarse" (figure 13a) with softening temperatures in the range $1320-1330^{\circ} \mathrm{C}$, clearly indicating partial melting.

\section{Figure $13-a)$, b) - Heating curves for synthetic and industrial raw meals. Heating rate: $10^{\circ} \mathrm{C} / \mathrm{min}$ in air. The volume decrease is shown on the ordinate.}

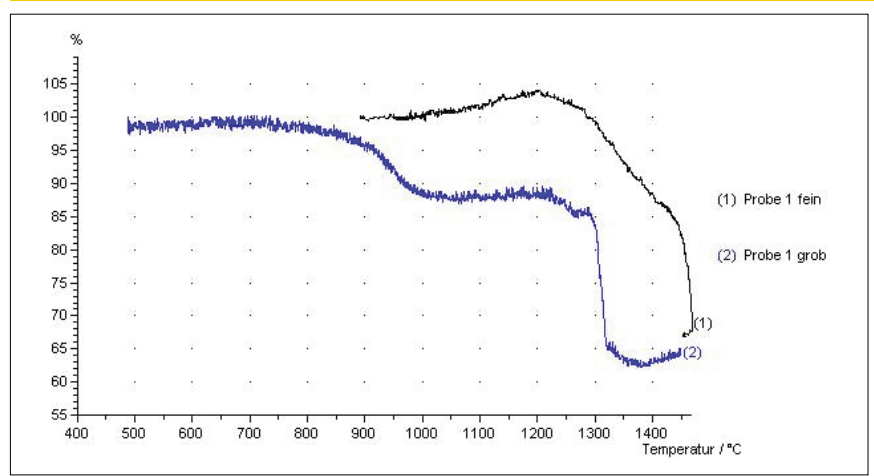

a) Curve (1, black) sample "fine", (2, blue) "coarse"

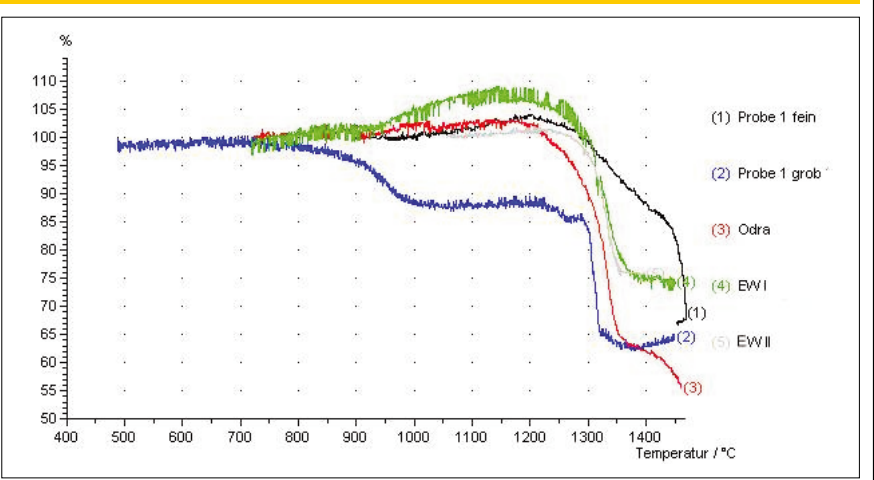

b) Curves $(1,2)$ as in figure $12 a$ Curves $(3,4,5)$ industrial raw meals 


\section{Conclusions}

Concerning the question, is it possible by coarsening the raw meal for cement production (going along with reduced energy consumption of the milling process) to achieve a controlled phase formation and eventually partial melting of a silica rich melt resulting in a "lower melting" eutectic, synthetic raw meals composed from Calcite p.a. resp. Warsteiner Kalk (pure limestone, Germany), quartz powder and pure Kaolinite were calcined. While in a first experimental run the components were in an average grain size of $<14$ $\mu \mathrm{m}$, in a second run the Calcite (Warsteiner Kalk) was chosen in the range $200-500 \mu \mathrm{m}$. As expected the "fine" raw meal followed the phase-theoretical path and finally led to a clinker with the according phase assemblage Alite, Belite and Aluminate. Using a coarse calcitic component, however, led to a displacement of the remaining composition ( $\mathrm{CaO}$ partially unavailable to the reaction) to higher $\mathrm{SiO}_{2}$ resp. $\mathrm{Al}_{2} \mathrm{O}_{3}$ contents. In fact it was possible to shift the remaining composition as such, that for a coarse mixture with a relation fine/coarse of 1:1 (with fine $<14 \mu \mathrm{m}$, and coarse 200-500 $\mu \mathrm{m}$, Warsteiner Kalk) a low melting peritectic with $1315^{\circ} \mathrm{C}$ was approached. Macroscopically the sample was already recognised to be partially molten. Increasing the temperature to $1450^{\circ} \mathrm{C}$ results in the desired clinker assemblage with a homogenous texture. For a so called "super coarse" mixture, where the total calcitic component was added as Warsteiner Kalk with a grain size $200-500 \mu \mathrm{m}$, the eutectic Wollastonite - Gehlenite - Anorthite with $1265^{\circ} \mathrm{C}$ was established. Thus it seems, that by coarsening the calcitic component of the raw meal a lower eutectic might be achieved.

Heating microscopy of the very same synthetic raw meals confirmed these observations. For a fine synthetic sample sintering was observed at $1223^{\circ} \mathrm{C}$ and weakening of the sample (partial melting) was observed at about $1463^{\circ} \mathrm{C}$, whereas the onset of softening for a coarse grained synthetic sample was at $1310^{\circ} \mathrm{C}$.

The onset of weakening for a coarse grained sample was at $1287^{\circ} \mathrm{C}$.

Various industrial raw meals were subjected to heating microscopy (static experiments have been performed as well, not described in the present paper), demonstrating similar features to the coarse resp. super coarse synthetic sample of this study: the softening temperatures are in the range $1310-1330^{\circ} \mathrm{C}$ ). Modifying one of the industrial raw meals with respect to the grain size of the calcitic component finally led to a softening onset at $1279^{\circ} \mathrm{C}$.

It can thus be stated, that a coarsening of the calcitic component of a raw meal for cement production is advisable and may lead to a significant cost reduction.

Anyhow, this is strongly dependant on the available resources. For each location an optimisation routine has to be performed. Some of the given calculations within this project are suitable to give a quick access to the parameters.

For a given raw meal a quick test run can be performed showing the onset of weakening. A static clinker calcination and routine reflected light observation reveals the texture of the clinker. Stepwise the optimum of coarsening is detected.

It is proposed to separately grind resp. mill two significantly different grain fractions. A "fine" fraction $<90 \mu \mathrm{m}$ should in principal contain the siliceous and argillaceous components, whereas the calcitic component may be according to the observations of this study in the range $200-500 \mu \mathrm{m}$. Considering the technical and economical realizability a ratio $4: 1$ lime-marl/limestone is proposed. However, increasing the pure limestone contend eventually leads to a "lower melting" eutectic. The lime-marl and of course the limestone itself will be fractured during the rotary kiln process due to the decarbonatisation of the calcitic component and thus increase the "fine" fraction. Coarsening the calcite bearing fraction of the raw meals thus results in significantly lower energy consumption for milling.

\section{Acknowledgements}

The preparative work of N. Nebolsin and the EPMA of I. Steinberger is highly acknowledged

\section{References}

[01] Lörke, P.; Lörke, A.: Verfahren zum Herstellen von Zementklinkern sowie dessen Vorrichtung. Europäische Patentschrift EP 0801636 B1, 2001

[02] Rankin, G. A; Wright, F. E.: The Ternary System $\mathrm{CaO}-\mathrm{Al}_{2} \mathrm{O}_{3}-\mathrm{SiO}_{2}$. Am. J. Sci., Ser. 4, 39, 1915; p.1-79.

[03] Taylor, H. F. W.: Cement Chemistry. Thomas Telford Publishing, London. 2nd edition, 1997

[04] Lindner, R.: Silikatbildung durch Reaktion im festen Zustand. Z. Phys. Chem., Neue Folge, Vol. 6, 1955; p. 129-142.

[05] Saxena, S. K.; Chatterjee, N.; Fei, Y; Shen, G.: Thermodynamic Data on Oxides and Silicates. Springer Verlag, Heidelberg, 1993

[06] Kubachewski, O.; Alcock, C. B.: Metallurgical Thermochemistry, $5^{\text {th }}$ Ed., Pergamon Press, Oxford, 1979

[07] Robie, R. A., Hemingway, B. S.:Thermodynamic properties of minerals and related substances at $298.15 \mathrm{~K}$ and 1 bar ( $10^{5}$ Pascals) pressure and at higher temperature. United States Geological Survey Bulletin, 2131, 1995 